\title{
PRECEDENTES NO NOVO CÓDIGO DE PROCESSO CIVIL $V$. AÇÕES COLETIVAS
}

\author{
PRECEDENTS IN NEW CODE OF CIVIL PROCEDURE $V$. CLASS ACTIONS
}

Ursula Ribeiro de Almeida*

\begin{abstract}
Resumo:
Os litígios de massa podem ser tutelados por ações coletivas, mas elas se mostraram insuficiente para lidar com o aumento exponencial da quantidade de processos. $\mathrm{O}$ novo Código de Processo Civil trata dos litígios de massa por meio da vinculação dos precedentes.

Palavras-chave: Precedentes no Novo Código de Processo Civil brasileiro. Ações coletivas.
\end{abstract}

\begin{abstract}
:
Mass claims can be settled by class actions, but they have been insufficient to deal with the exponential increase in the number of cases. The new Code of Civil Procedure deals with mass claims by binding precedent.
\end{abstract}

Keywords: Precedents in New Brazilian Code of Civil Procedure. Class actions.

\section{Introdução}

Desde as décadas 60 e 70 do século passado, multiplicam-se os litígios de massa, relativos a grupos indeterminados de pessoas, especialmente em direito do consumidor e direito ambiental. A segunda onda renovatória do processo civil ${ }^{1}$ buscou adaptar as técnicas do processo civil tradicional para esse novo tipo de demanda, que levou à criação e aprimoramento das ações coletivas.

No direito brasileiro, ampliou-se o cabimento da ação popular para tutelar de forma mais ampla os direitos coletivos. Em 1985, criou-se a lei da ação civil pública, que é o instrumento mais importante para tutela coletiva de direitos. A Constituição Federal de 1988 criou o mandado de segurança coletivo, que era instituto tradicionalmente vinculado aos direitos individuais. Em 1990, o Código de Defesa do Consumidor ampliou ainda mais a tutela coletiva de direitos.

Embora a tutela coletiva de direitos tenha evoluído significativamente, os litígios de massa continuaram a se multiplicar em todas as instâncias. Os tribunais superiores enfrentam acúmulo intransponível de recursos. Muitos desses litígios são

\footnotetext{
Mestre em Processo Civil pela Faculdade de Direito da Universidade de São Paulo.

1 CAPELletTI, Mauro; GARTH, Bryant. Acesso à justiça. Trad.: Ellen Gracie Northfleet. Porto Alegre: Sergio Antonio Fabris, 1988. p. 18-19.
} 
provocados pelos mesmos litigantes: o Poder Público, as concessionárias de serviço público e as instituições financeiras.

Além disso, a jurisprudência se mostrou incapaz de dar tratamento isonômico e estável para esse tipo de conflito, que compromete a confiança do cidadão no Poder Judiciário. As instâncias inferiores não observam ou ignoram o entendimento dos tribunais superiores sobre relevantes questões de direito. As Cortes Superiores, por sua vez, muitas vezes não têm compromisso com a uniformidade da sua jurisprudência.

A ampliação da legitimidade e dos tipos de ação de controle concentrado de constitucionalidade não foi suficiente para superar as divergências quanto à interpretação do direito pelas instâncias inferiores.

Ainda que o Novo Código de Processo Civil (NCPC) não tenha alterado a disciplina legal das ações coletivas e das ações de controle concentrado de constitucionalidade, vemos um esforço do legislador para lidar com os conflitos de massa de maneira isonômica e eficaz por meio da valorização dos precedentes judiciais e do aprimoramento de técnicas para uniformizar a interpretação do direito.

\section{Precedentes}

Tradicionalmente, distingue-se os sistemas da Common Law e da Civil Law com base na fonte do direito; no primeiro é a decisão judicial e no segundo a lei escrita. No entanto, essa distinção se tornou anacrônica nas últimas décadas, pois ambos os sistemas usam as leis escritas e os precedentes para solução de litígios. Algumas matérias são inteiramente codificadas em países que adotam o sistema da Common Law, enquanto a jurisprudência ${ }^{2}$ é inegável fator de interpretação do direito nos países da Civil Law. ${ }^{3}$

Os países da Civil Law passaram a valorizar os precedentes em busca da aplicação e interpretação do direito de maneira uniforme. A jurisprudência coerente evita que as decisões sejam variáveis sobre questões semelhantes ou iguais, garantindo segurança jurídica ao jurisdicionado. ${ }^{4}$ Além disso, o sistema de precedentes implica em aplicação do princípio da igualdade, já que adota o mesmo entendimento para situações

$2 \quad$ Ajurisprudência é formada por um conjunto de decisões que adota o mesmo entendimento sobre determinada matéria (CAMBI, Eduardo; FOGAÇA, Mateus Vargas. Sistema dos precedentes judiciais obrigatórios no Novo Código de Processo Civil. In: DIDIER JR., Fredie et al (Coord.). Precedentes. Salvador: Juspodivm, 2015. v. 3. (Coleção grandes temas do novo CPC). p. 343.).

3 TARUFFO, Michele. Precedente e jurisprudência. Revista de Processo, São Paulo, ano 36, v. 199, p. 139191, set. 2011. p. 140.

4 TARUFFO, Michele. Le funzioni delle Corti Supreme tra uniformità e giustizia. In: DIDIER JR., Fredie et al (Coord.). Precedentes. Salvador: Juspodivm, 2015. v. 3, p. 251-262. (Coleção grandes temas do novo CPC). p. 251. 
iguais ou parecidas. Os jurisdicionados podem definir previamente as suas expectativas, fazendo escolha mais segura antes de ajuizar a demanda ou firmar um acordo. ${ }^{5}$

De outro lado, a adoção de precedentes tem alguns aspectos negativos porque há risco de estagnação do direito ao se repetir decisões anteriores. ${ }^{6}$ Também é possível que os julgadores não examinem o caso de maneira criteriosa porque ficam acomodados com a aplicação do precedente. ${ }^{7}$ A falta de tradição do uso de precedentes pode levar à sua aplicação como norma jurídica, sem confronto com o caso objeto do julgamento e os pressupostos fáticos do precedente. ${ }^{8}$

\subsection{Precedentes no sistema da Civil Law}

A França tradicionalmente rejeita o uso de decisões judiciais como fonte de normas jurídicas porque após a Revolução Francesa se consolidou a ideia que apenas o Poder Legislativo tem legitimidade para criar normas. ${ }^{9} \mathrm{O}$ art. $5^{\circ}$ do Código Civil francês veda o julgamento de litígios com fundamento em decisão proferida em caso anterior, já que os juízes não podem criar normas para casos futuros. ${ }^{10}$

No entanto, as decisões do Conseil Constitutionnel são vinculantes aos demais poderes quando proferida pela Assemblée Plénière ao apreciar recurso contra decisão que não observou sua decisão anterior sobre a mesma matéria. Além disso, é comum os juízes adotarem o mesmo fundamento de direito sobre matéria com entendimento consolidado na jurisprudência. ${ }^{11}$ Embora os precedentes não sejam vinculantes, é possível afirmar que há certo grau de força normativa, que é visto como enigma pela doutrina francesa devido à tradição da rígida separação de Poderes. ${ }^{12}$

Na Alemanha, algumas decisões da Corte Constitucional Federal e das Cortes Constitucionais Estaduais são vinculantes. Além disso, os juízes tendem a respeitar

5 MARINONI, Luiz Guilherme. Precedentes obrigatórios. 2. ed. São Paulo: Revista dos Tribunais, 2011. p. 120-182.

6 Os direitos inglês e estadunidense têm mecanismos para superação de precedente quando se torna incompatível com a nova realidade fática (MARINONI, Luiz Guilherme. Precedentes obrigatórios ... cit., p. 193).

7 SCHAUER, Frederick. Precedente. In: DIDIER JR., Fredie et al (Coord.). Precedentes. Salvador: Juspodivm, 2015. v. 3. (Coleção grandes temas do novo CPC). p. 79.

8 BARREIROS, Lorena Miranda Santos. Estruturação de um sistema de precedentes no Brasil e concretização da igualdade: desafios no contexto de uma sociedade multicultural. In: DIDIER JR., Fredie et al (Coord.). Precedentes. Salvador: Juspodivm, 2015. v. 3. (Coleção grandes temas do novo CPC). p. 189.

9 STEINER, Eva. Theory and practice of judicial precedent in France. In: DIDIER JR., Fredie et al (Coord.). Precedentes. Salvador: Juspodivm, 2015. v. 3. (Coleção grandes temas do novo CPC). p. 21.

$10 \quad$ Id. Ibid., p. 22-24.

11 Id. Ibid., p. 26-27.

12 Id. Ibid., p. 29-38. 
a jurisprudência das Cortes Superiores, embora suas decisões não sejam vinculantes. É inegável que os precedentes exercem papel importante nas decisões judiciais alemãs. ${ }^{13}$

$\mathrm{Na}$ Itália, os precedentes não são vinculantes, mas as decisões das Cortes Superiores exercem efeito persuasivo em relação aos juízes inferiores. Ainda que as decisões judiciais não sejam tratadas pela doutrina como fonte do direito, ela exerce influência na interpretação e apreciação das leis para solução do caso concreto. ${ }^{14}$

$\mathrm{Na}$ Rússia observa-se fenômeno recente de uso da decisão judicial como fonte do direito, já que as cortes adotam o entendimento de decisões anteriores sobre o mesmo tema objeto do julgamento. ${ }^{15}$

Em alguns países da América Latina, observa-se tendência de valorização dos precedentes, já que as decisões da Corte Constitucional muitas vezes são vinculantes ou têm, pelo menos, efeito persuasivo. No processo civil chileno e colombiano, as decisões do Tribunal Constitucional têm caráter persuasivo perante as instâncias inferiores, mesmo quando não são vinculantes. ${ }^{16}$ As decisões da Suprema Corte de Justiça mexicana são vinculantes em relação aos órgãos judiciários inferiores. Embora no Paraguai os precedentes não sejam vinculantes, é adotada como frequência pelos juízes como fundamentação. ${ }^{17}$ Ressalvamos que no direito argentino os precedentes não têm relevância prática. ${ }^{18}$

\subsection{Precedentes no direito brasileiro}

Assim como os demais países de tradição da Civil Law, o direito brasileiro passou a valorizar os precedentes judiciais, especialmente das Cortes Superiores, como

13 KERN, Christoph A. The respect for court decisions in German Law. In: MENDES, Aluísio Gonçalves de Castro; WAMBIER, Teresa Arruda Alvim (Org.). O processo em perspectiva: jornadas brasileiras de direito processual. São Paulo: Revista dos Tribunais, 2013. p. 143-144.

14 BASCHIERA, Marinella. Introduction to the Italian legal system. The allocation of normative powers: issues in law finding. International Journal of Legal Information, Ann Arbor, v. 34, n. 2, p. 279-326, Summer 2006. p. 279-326.

15 HENDERSON, Jane. Precedent as a source of law in the russian legal system. In: DIDIER JR., Fredie et al (Coord.). Precedentes. Salvador: Juspodivm, 2015. v. 3. (Coleção grandes temas do novo CPC). p. 100.

16 LEONEL, Ricardo de Barros. Direito processual civil chileno. In: TUCCI, José Rogério Cruz e (Coord.). Direito processual civil americano contemporâneo. São Paulo: Lex Editora, 2010. p. 90-91; SICA, Heitor Vitor Mendonça. Direito processual civil colombiano. In: TUCCI, José Rogério Cruz e (Coord.). Direito processual civil americano contemporâneo. São Paulo: Lex Editora, 2010. p. 124.

17 GRINOVER, Ada Pellegrini. O processo. II série: estudos e pareceres de processo civil. Brasília: Gazeta Jurídica, 2013. p. 1.191-1.192.

18 SALGADO, José María. Precedentes y control de constitucionalidad en Argentina. In: DIDIER JR., Fredie et al (Coord.). Precedentes. Salvador: Juspodivm, 2015. v. 3. (Coleção grandes temas do novo CPC). p. 145146; ARDOY, Leandro A.; MOSMANN, María Victoria. Algunas cuestiones acerca de la jurisprudencia uniforme y los amicus curiae. In: DIDIER JR., Fredie et al (Coord.). Precedentes. Salvador: Juspodivm, 2015. v. 3. (Coleção grandes temas do novo CPC). p. 701-702. 
mecanismo para manter a coerência da ordem jurídica. O Código de Processo Civil de 1973 não previa vinculação dos precedentes, que provocava diversas críticas devido à não observância da jurisprudência consolidada dos tribunais superiores e à mudança frequente de entendimento dos mesmos tribunais sobre assuntos relevantes.

Para mudar essa realidade, o novo Código visa atribuir maior eficácia aos precedentes. O art. 927 do Novo Código de Processo Civil prevê a vinculação de alguns precedentes e das súmulas aos órgãos do Poder Judiciário: a) decisões do Supremo Tribunal Federal em ação de controle concentrado de constitucionalidade, que é redundante porque elas produzem efeitos erga omnes; b) enunciado de súmula vinculante, cuja previsão também é desnecessária porque ela vincula inclusive a Administração Pública (art. 103A, caput, da $\mathrm{CF} / 88^{19}$ ); c) acórdãos em sede de incidente de assunção de competência, Incidente de Resolução de Demanda Repetitiva (IRDR) e julgamento de recursos especial e extraordinários repetitivos; d) enunciados de súmulas do Supremo Tribunal Federal (STF) e Superior Tribunal de Justiça (STJ); e) orientação do plenário ou órgão especial do tribunal local.

Primeiramente, destacamos que as súmulas ${ }^{20}$ não podem ser consideradas precedentes por não terem contexto fático e sim breve resumo da tese predominante da jurisprudência do tribunal, ${ }^{21}$ mas trataremos conjuntamente com os precedentes porque a disciplina legal da sua vinculação é semelhante.

De um lado, defende-se que o rol do art. 927 do $\mathrm{NCPC}^{22}$ não é taxativo porque todas as decisões judiciais devem aplicar os precedentes e enunciados de súmula, explicando a sua semelhança com o caso objeto de julgamento, sob pena de ser considerada não fundamentada (art. 489, § $1^{\circ}, \mathrm{V}$ e VI, do NCPC). De outro lado, a sua constitucionalidade é questionável porque apenas as súmulas vinculantes e as decisões em

19 Constituição Federal de 1988.

20 A súmula se origina dos assentos obrigatórios do direito português, cuja finalidade "era de dar destaque a um julgado diferenciado pela especialidade da matéria nele versada, por modo que assim ele passasse a operar como paradigma obrigatório para os casos análogos" (MANCUSO, Rodolfo de Camargo. Divergência jurisprudencial e súmula vinculante. 4. ed. São Paulo: Revista dos Tribunais, 2010. p. 222). No Brasil, os assentos da Casa de Suplicação eram vinculantes mesmo após a Independência e a promulgação da Constituição Federal de 1824 (Idem, p. 223-225). Em 1963, Vitor Nunes Leal liderou alteração no regimento do STF para prever a criação de súmulas de jurisprudência dominante, que autorizava o relator a arquivar recurso extraordinário ou agravo de instrumento em contradição com a súmula (DINAMARCO, Cândido Rangel. Instituições de direito processual civil. 8. ed. São Paulo: Malheiros, 2016. v. 1. p. 158). A Emenda Constitucional n. 45/2004 introduziu as súmulas vinculantes do STF, que dependem de aprovação por procedimento específico e vinculam o Poder Judiciário e a Administração pública direta e indireta (art. 103-A, caput, da CF/88).

21 MARINONI, Luiz Guilherme. Julgamentos nas Cortes Supremas: precedentes e decisão do recurso diante do novo CPC. São Paulo: Revista dos Tribunais, 2015. p. 23.

22 Novo Código de Processo Civil. 
ação de controle concentrado de constitucionalidade são vinculantes, ${ }^{23}$ bem como o Poder Judiciário não teria legitimidade política para criar lei. ${ }^{24}$

A adoção dos precedentes exige a seleção dos casos similares julgados anteriormente, que devem ser confrontados com o caso a ser decidido. A regra jurídica contida no precedente deve ser identificada (ratio decidendi) e aplicada ao caso objeto do julgamento, ou não aplicada para superá-la em razão da perda da congruência social ou sistêmica (overruling). Mas também é possível afastar o precedente se as circunstâncias fáticas não forem similares ao caso que será julgado (distinguishing). ${ }^{25}$

Como não há uma tradição na adoção dos precedentes pelos países do sistema da Civil Law, enfrenta-se dificuldade para identificar a regra jurídica abstrata e também na comparação das circunstâncias fáticas, já que os tribunais tradicionalmente não fazem relato detalhado dos fatos, dificultando a comparação com o caso objeto de julgamento. ${ }^{26}$ Por isso, o novo Código exige que sejam adotadas as técnicas da identificação da ratio decidendi e do distinguishing ao exigir que os juízes e tribunais confrontem o caso objeto do julgamento com o precedente (art. 927, § 1, c/c art. 489, § $1^{\circ}$, IV e V, ambos do NCPC). ${ }^{27}$

Ademais, os tribunais devem ter especial cautela ao proferir decisão porque pode se tornar um precedente. ${ }^{28} \mathrm{O}$ Novo Código enfatiza a importância da fixação da tese (art. 926, caput, do NCPC) e as implicações da modificação do entendimento, já que exige que os tribunais considerem "os princípios da segurança jurídica, da proteção da confiança e da isonomia" (art. 927, § $4^{\circ}$, do NCPC). Busca-se combater a jurisprudência instável dos tribunais superiores. ${ }^{29}$

23 TUCCI, José Rogério Cruz e. O regime do precedente judicial no novo CPC. In: DIDIER JR., Fredie et al (Coord.). Precedentes. Salvador: Juspodivm, 2015. v. 3. (Coleção grandes temas do novo CPC). p. 454.

24 MAZZILLI, Hugo Nigro. O processo coletivo e o Código de Processo Civil de 2015. In: ZANETI JR., Hermes (Coord.). Processo coletivo. Salvador: Juspodivm, 2016. (Coleção repercussões do novo CPC, v. 8). p. 198-199.

25 SCHAUER, Frederick. Precedentes ... cit., p. 55-74.

26 TARUFFO, Michelle. Precedente e jurisprudência ... cit., p. 144.

27 As técnicas para aplicação dos precedentes sofrem críticas, pois os juízes perderiam autonomia interpretativa e ficariam vinculados às decisões dos tribunais que têm interesse político-partidário (MAZZILLI, Hugo Nigro. O processo coletivo ... cit., p. 194). Embora o sistema de vinculação dos precedentes seja problemática devido à falta de tradição no direito brasileiro, não se pode negar que implica em racionalização no julgamento de recursos.

28 SCHAUER, Frederick. Precedentes ... cit., p. 51.

29 José Rogério Cruz e Tucci aponta que: “acerca de inúmeras questões importantes há flagrante e indesejada instabilidade nos precedentes dos tribunais superiores. E isso ocorre - o que é pior - num mesmo momento temporal e sem qualquer justificação plausível!” (TUCCI, José Rogério Cruz e. O regime do precedente judicial no novo CPC ... cit., p. 449). 


\subsubsection{Mecanismos para vinculação dos precedentes no NCPC}

O Novo Código prevê diversos mecanismos para vinculação dos precedentes e súmulas. Um deles é o cabimento de tutela de evidência quando a alegação de fato depender de prova exclusivamente documental e houver tese firmada em recursos repetitivos, ou súmula vinculante, sobre a questão de direito objeto da demanda (art. 311, II, do NCPC).

Antes mesmo da citação do réu, a ação pode ser julgada liminarmente improcedente se o pedido contrariar súmula do STF ou do STJ, acórdão proferido pelo STF ou STJ no julgamento de recursos extraordinário ou especial repetitivos, entendimento firmado em IRDR ou incidente de assunção de competência e súmula do tribunal de justiça sobre direito local (art. 332, I a IV, do NCPC).

Todas as decisões judiciais deverão enfrentar os precedentes e súmulas sobre a matéria objeto da demanda, demonstrando "que o caso sob julgamento se ajusta àqueles fundamentos" ou "a existência de distinção no caso em julgamento ou a superação do entendimento" (art. 489, § $1^{\circ}, \mathrm{V}$ e VI, do NCPC). Assim, não poderá o juiz ou tribunal ignorar ou simplesmente transcrever súmulas ou precedentes sobre o tema.

A remessa necessária da sentença contrária aos interesses da Fazenda Pública nos procedimentos disciplinados pelo Código é dispensada quando a decisão estiver fundada em súmula de tribunal superior, acórdão proferido em sede de recursos especial e extraordinário repetitivos e entendimento firmado em IRDR ou incidente de assunção de competência (art. 498, § 4 , I a III, do NCPC).

O título executivo judicial será considerado inexigível quando fundado em lei, ato normativo ou interpretação, considerado inconstitucional ou incompatível com a Constituição Federal pelo STF em sede de controle concentrado ou difuso de constitucionalidade. $\mathrm{O}$ executado poderá opor impugnação ao cumprimento de sentença para impedir a sua execução (art. 525, § 12, do NCPC).

$\mathrm{O}$ relator de qualquer recurso, por decisão monocrática, deve negar provimento a recurso contrário a súmula do STF, do STJ ou do tribunal que estiver vinculado, acórdão proferido pelos tribunais superiores em sede de recursos especial ou extraordinários repetitivos e entendimento firmado em IRDR ou incidente de assunção de competência (art. 932, IV, "a" a "c", do NCPC). Após a apresentação das contrarrazões, o relator deverá dar provimento ao recurso interposto contra decisão que contrariar as súmulas e as decisões mencionadas anteriormente (art. 932, V, "a" a "c", do NCPC).

No conflito de competência, o relator pode julgá-lo liminarmente e monocraticamente quando sua decisão se fundar em súmula do STF, do STJ ou do tribunal que estiver vinculado, em tese firmada no julgamento de recursos especial ou 
extraordinário repetitivos, IRDR ou incidente de assunção de competência (art. 955, par. único, I e II, do NCPC).

É cabível ação rescisória se a decisão impugnada foi proferida com fundamento em lei, ato normativo ou interpretação declarada inconstitucional ou incompatível com a Constituição Federal em sede de controle concentrado ou difuso de constitucionalidade pelo STF. O prazo para ajuizamento da ação rescisória se inicia após o trânsito em julgado da decisão do STF (art. 525, §§ 12 e 15, do NCPC).

Por fim, a parte interessada ou o Ministério Público podem apresentar reclamação contra decisão que contrariar súmula vinculante e decisão proferida em IRDR e incidente de assunção de competência (art. 988, III, do NCPC). A reclamação será apresentada ao tribunal cuja competência se busca preservar (art. 988, $\S 1^{\circ}$, do NCPC). ${ }^{30}$

A sistemática do Novo Código de Processo Civil permite afirmar que os precedentes originários dos processos-modelo - IRDR, recursos especial e extraordinário repetitivos e incidente de assunção de competência - são fontes formal do direito devido ao seu caráter vinculante. ${ }^{31}$ Além disso, a jurisprudência de forma geral tem efeito persuasivo, já que é usada pelos juízes e tribunais como repositório de norma jurídica. ${ }^{32}$

Veremos os procedimentos dos processos-modelo do qual se originam relevantes precedentes vinculantes.

\section{Processo-modelo}

\subsection{Processo-modelo no direito comparado}

Alguns países da Civil Law e da Common Law adotam o processo-modelo como mecanismo para proferir uma única decisão nos diversos casos em que se discute a mesma questão de fato ou de direito. É uma forma de racionalizar o julgamento de demandas repetitivas. Vejamos alguns países que adotam esse mecanismo, com especial ênfase no direito alemão porque inspirou o Incidente de Resolução de Demandas Repetitivas no Novo Código de Processo Civil. ${ }^{33}$

Entre 2001 e 2003, centenas de investidores, representados por diferentes advogados, processaram o Deutsche Telekom alegando divulgação de informação falsa. A lentidão dos processos levou os interessados a interpor recurso perante a Corte

30 A reclamação independe do julgamento do recurso eventualmente interposto contra a decisão objeto da reclamação. Além disso, não há prazo para sua propositura, desde que seja antes do trânsito em julgado (art. 988, $\S \S 5^{\circ}$ e $6^{\circ}$, do NCPC).

31 ZANETI JR., Hermes. Precedentes normativos formalmente vinculantes. In: DIDIER JR., Fredie et al (Coord.). Precedentes. Salvador: Juspodivm, 2015. v. 3. (Coleção grandes temas do novo CPC). p. 409.

32 DINAMARCO, Cândido Rangel. Instituições de direito ... cit., p. 160-161.

33 Exposição de motivos do Anteprojeto do Novo Código de Processo Civil, Brasília, 2010. 
Constitucional para alegar negativa de acesso à justiça. O recurso foi rejeitado, mas a Corte recomendou o uso de um procedimento-modelo. ${ }^{34}$ Após ampla discussão acadêmica, o processo-modelo passou a ser adotado pela legislação que disciplina o mercado de capitais, seguros e processos administrativos. ${ }^{35}$

O procedimento se inicia com o pedido das partes, que deverá demonstrar que há quantidade significativa de processos semelhantes. O pedido deverá ser amplamente divulgado para que outros interessados possam participar do processo-modelo. ${ }^{36} \mathrm{O}$ pedido somente será remetido à corte superior se forem apresentados outros nove no prazo de seis meses. $^{37}$

A Corte de apelação deverá escolher o caso modelo com maior abrangência de argumentos e indicado pelas partes interessadas em comum acordo. A Corte deverá divulgar amplamente o caso escolhido e suspender de ofício os processos pendentes sobre a mesma questão. ${ }^{38}$

Aqueles que não são partes no processo escolhido como modelo poderão se manifestar em observância ao direito constitucional de ser ouvido. O julgamento será vinculante para as partes do processo e para os demais processos pendentes, mas não para os casos futuros. ${ }^{39}$

Em 2000, o Código de Processo Civil inglês foi reformado para introduzir o Group Litigation Order (GLO), que é uma forma especial de julgamento conjunto de processos com questão de fato ou direito comum. A decisão sobre a questão comum é vinculante para o todo o grupo. ${ }^{40}$

A legislação federal dos Estados Unidos adota o Multidistrict Litigation para unificar o procedimento na fase de prejulgamento quando há centenas de ações ajuizadas, em diferentes distritos, sobre a mesma questão contra um demandado ou pequeno número

34 BAETGE, Dietmar. Class actions, group litigation \& other forms of collective litigation: Germany. Global Class Actions Exchange, Stanford, 2007. Disponível em: <http:/globalclassactions.stanford.edu/sites/ default/files/documents/Germany_National_Report.pdf $>$. Acesso em: 25 maio 2016. p. 7-8.

35 Id. Ibid., p. 9-10.

36 Id. Ibid., p. 15.

37 "Section 6. Reference to the Higher Regional Court; Power to Issue Statutory Instruments (1) The court trying the matter shall order the referral of the decision on the establishment objective of related applications for the establishment of a model case to the Higher Regional Court which is the higher court of instance if at least nine other related applications for the establishment of a model case have been announced within six months after the first announcement of an application for the establishment of a model case. The order referring the matter to a higher court of instance shall be without appeal and binding for the Higher Regional Court." (ACT on model case proceedings in disputes under capital markets law. Translation provided by Jane Yager for the Federal Ministry of Justice and Consumer Protection. Disponível em: <http://www. gesetze-im-internet.de/englisch_kapmug/englisch_kapmug.pdf>. Acesso em: 12 abr. 2016.).

38 BAETGE, Dietmar. Class actions ... cit., p. 15-19.

39 Id. Ibid., p. 20.

40 ANDREWS, Neil H. Multi-party litigation in England. Legal Studies Research Paper Series, Cambridge, n. 39 , p. 1-15, set./2013. p. 8-11. 
de demandados. Esse procedimento passou a ser usado em 1968 quando foram ajuizadas mais de duas mil ações de direito concorrencial em 33 distritos federais diferentes contra fabricantes de equipamentos elétricos. ${ }^{41}$

\subsection{Processo-modelo no direito brasileiro}

Os Tribunais Superiores brasileiros recebem volume cada vez maior de recursos, que inviabiliza a sua efetiva apreciação em tempo razoável. Muitas vezes os recursos tratam de questões de direito semelhantes ou, até mesmo, iguais. A quantidade excessiva de recursos levou as Cortes Superiores a proferirem decisões contraditórias sobre a mesma questão.

Para superar o problema de excesso de recurso e manter a coerência das decisões, o Supremo reformou seu regimento em 2003 para prever sistema de julgamento de recurso extraordinário repetitivo contra decisões proferidas por juizados especiais. Em 2006, o Código de Processo Civil de 1973 foi reformado para estender o uso do mecanismo de julgamento de recurso repetitivo para todos os recursos extraordinários (art. 543-B introduzido pela Lei n. 11.418/2006). Em 2008, a técnica foi estendida para o julgamento de recurso especial pelo Superior Tribunal de Justiça (art. 543-C introduzido pela Lei n. 11.672/2008). ${ }^{42}$

O Novo Código de Processo Civil incorporou a técnica do processomodelo e ampliou seu cabimento para outros recursos interpostos perante as Cortes locais, Tribunais de Justiça e Tribunais Regionais Federais. Veremos os aspectos gerais das técnicas introduzidas pelo novo Código.

\subsubsection{Incidente de Resolução de Demandas Repetitivas (IRDR)}

O Incidente de Resolução de Demandas Repetitivas (IRDR) pode ser suscitado ao Presidente do Tribunal pelo juiz ${ }^{43}$ ou relator, de ofício, pelas partes, pelo

$41 \quad$ SILVER, Courtney E. Procedural hassles in multidistrict litigation: a call for reform of 28 U.S.C. $\S 1407$ and the Lexecon Result. Ohio State Law Journal, Ohio, v. 70, n. 2, p. 455-486, 2009. Disponível em: <http:// moritzlaw.osu.edu/students/groups/oslj/files/2012/03/70.2.silver.pdf $>$. p. 455-459.

42 TALAMINI, Eduardo. A dimensão coletiva dos direitos individuais homogêneos: ações coletivas e os mecanismos previstos no Código de Processo Civil de 2015... In: ZANETI JR., Hermes (Coord.). Processo coletivo. Salvador: Juspodivm, 2016. (Coleção repercussões do novo CPC, v. 8). p. 123.

43 O incidente suscitado pelo juiz de primeiro grau demanda cautela, já que é necessário verificar o amadurecimento da questão em segundo grau para evitar decisão sobre tese pouco debatida. Por isso, é mais apropriado que o incidente seja suscitado em processos que tramitam em segundo grau (MENDES, Aluísio Gonçalves de Castro; TEMER, Sofia. O incidente de resolução de demandas repetitivas no novo Código de processo Civil. ZANETI JR., Hermes (Coord.). Processo coletivo. Salvador: Juspodivm, 2016. (Coleção repercussões do novo CPC, v. 8). p. 594-596). 
Ministério Público ou pela Defensoria Pública (art. 977, do NCPC). Os legitimados deverão demonstrar a repetição de processos sobre a mesma questão de direito ${ }^{44}$ e risco de violação da isonomia e segurança jurídica (art. 976, I e II, do NCPC). O incidente não será cabível se os tribunais superiores afetaram recurso sobre a questão de direito repetitiva (art. 976, § $4^{\circ}$, do NCPC).

O Ministério Público deverá atuar como fiscal da lei nos casos em que não suscitar o incidente (art. 976, $\S 2^{\circ}$, do NCPC), mesmo que se trate apenas de direitos privados de natureza patrimonial porque a decisão será “exponencialmente relevante para a promoção do respeito à ordem jurídica". ${ }^{45}$

$\mathrm{O}$ incidente será apreciado pelo órgão indicado pelo regimento interno do tribunal como competente para uniformização de jurisprudência. Após o juízo de admissibilidade, o relator do incidente deverá determinar a suspensão de todos os processos, individuais e coletivos, sobre a mesma questão que tramitar perante as instâncias inferiores, cujos juízes competentes deverão ser devidamente comunicados (arts. 981, 982, I e $\S 1^{\circ}$, do NCPC). ${ }^{46}$ Se houver outro pedido independente da questão objeto do incidente, o processo deverá prosseguir sua apreciação.

As partes, o Ministério Público e a Defensoria Pública poderão requerer a suspensão dos processos em todo território nacional ao STJ ou ao STF para garantir a segurança jurídica (art. 982, § $3^{\circ}$, do NCPC). Além disso, a parte de processo que não está inserida no limite territorial do tribunal poderá requerer a suspensão do seu processo que tratar da mesma questão de direito (art. 982, $4^{\circ}$, do NCPC).

O Código é omisso quanto à indevida suspensão de processo que não tratar da mesma questão de direito objeto do incidente. Nesse caso, é recomendável que se aplique por analogia o procedimento do julgamento dos recursos especial e extraordinário repetitivos (art. $1.037, \S \S 9^{\circ}$ a $13^{\circ}$, do NCPC)..$^{47}$

44 Há quem defenda que o IRDR deveria ser cabível também para questão de fato repetitiva (TALAMINI, Eduardo. A dimensão coletiva ... cit., p. 125-126).

45 A atuação do Ministério Público como fiscal da lei tem o mesmo fundamento da sua atuação nas ações coletivas e de controle concentrado de constitucionalidade (LEONEL, Ricardo de Barros. Intervenção do Ministério Público no incidente de resolução de demandas repetitivas. Revista Jurídica da Escola Superior do Ministério Público de São Paulo, São Paulo, v. 1, p. 173-185, 2012. p. 182-183).

46 Ao contrário da sistemática do Código de 1973 no qual se suspendiam processos em fase recursal que aguardavam a solução da mesma questão de direito, o IRDR prevê a suspensão de todos os processos que estão em fase distintas. Para Hugo Nigro Mazzilli, a suspensão ampla de processos implica em negativa de acesso à justiça porque o IRDR impede a instrução e julgamento (MAZZILLI, Hugo Nigro. O processo coletivo ... cit., p. 198).

47 DANTAS, Bruno. Comentários ao artigo 982. In: WAMBIER, Teresa Arruda Alvim; DIDIER JR., Fredie; TALAMINI, Eduardo; DANTAS, Bruno (Coord.). Breves comentários ao novo código de processo civil. 2. tir. São Paulo: Revista dos Tribunais, 2015. p. 2.189-2.190. 
A disciplina legal do IRDR também é omissa quanto aos critérios para escolha do processo representativo da controvérsia quanto à questão de direito. A escolha deve priorizar aquela que trata de forma mais ampla as teses jurídicas objeto da controvérsia. ${ }^{48}$ Critica-se a falta de participação das partes na escolha do processo-modelo, que depois ficarão vinculadas à tese jurídica fixada. ${ }^{49}$ É recomendável selecionar vários casos, já que submeter "um único processo piloto pode violar a igualdade substancial na medida em que a demanda individual pode não explorar todos os pontos que seriam favoráveis ao demandante". ${ }^{50}$

O problema pode ser minimizado com a necessária participação do Ministério Público (art. 982, III, do NCPC) e a possibilidade de manifestação dos interessados na solução da controvérsia (art. 983, caput, do NCPC). O relator poderá inclusive designar audiência pública para ouvir "pessoas com experiência e conhecimento na matéria" (art. 983, § $1^{\circ}$, do NCPC).

Ademais, pode-se aplicar por analogia os critérios para seleção do recurso especial ou extraordinário representativos da controvérsia, que deverão ser pelo menos dois e devem conter abrangente argumentação e discussão sobre a questão de direito que será decidida (art. $1.036, \S \S 1^{\circ}$ e $6^{\circ}$, do NCPC).

O incidente deverá ser julgado no prazo máximo de um ano, pois após esse período os processos suspensos deverão voltar a tramitar, salvo decisão do relator em sentido contrário (art. 980, do NCPC). É necessária a estrita observância do prazo legal, já que a prorrogação da suspensão implica em negativa de acesso à justiça porque impede a apreciação da demanda ou do recurso. ${ }^{51}$

A tese firmada no incidente deverá ser aplicada a todos os processos pendentes e futuros na jurisdição do tribunal que o decidiu pelos respectivos juízos competentes (art. 985, I e II, do NCPC).

O Tribunal competente para o julgamento do IRDR deverá dar ampla publicidade à instauração do incidente e seu julgamento para garantir que todos os interessados na decisão da questão de direito tenham ciência. As informações do incidente deverão constar em banco eletrônico atualizado do tribunal e serem remetidas ao Conselho Nacional de Justiça (art. 979, do NCPC).

48 MENDES, Aluisio Gonçalves de Castro; TEMER, Sofia. O incidente de resolução ... cit., p. 598-599.

49 CAVALCANTI, Marcos de Araújo. A falta de controle judicial da adequação da representatividade no Incidente de Resolução de Demandas Repetitivas (IRDR). Revista Pensamento Jurídico, São Paulo, v. 7, n. 1, p. 30-47, 2015. p. 42-44.

50 LUCON, Paulo Henrique dos Santos. Relação entre demandas. Tese (Livre Docência) - Faculdade de Direito, Universidade de São Paulo, São Paulo, 2015. p. 211.

51 Destacamos a crítica de Hugo Nigro Mazzilli quanto à "suspensão arbitrária dos processos individuais, ou seja, suspensão do acesso à justiça: essa é a verdade" (MAZZILLI, Hugo Nigro. O processo coletivo ... cit., p. 197). 
O novo Código superou problema enfrentado pelo Superior Tribunal de Justiça quanto à possibilidade de desistência do recurso especial modelo na apreciação do recurso repetitivo. ${ }^{52} \mathrm{O}$ Tribunal entendeu que a parte não poderia desistir, mas o Novo Código admite a desistência ou abandono do processo-modelo, pois não obsta a apreciação do incidente e o Ministério Público sucederá a parte no referido incidente (art. $976, \S \S 1^{\circ}$ e $2^{\circ}$, do NCPC).

A decisão do incidente pode ser impugnada por recurso especial ou extraordinário, cujo legitimado para interpor é a parte do processo-modelo ou qualquer outro interessado afetado pela decisão do recurso repetitivo como terceiro prejudicado (art. 996, do NCPC) ${ }^{53} \mathrm{O}$ recurso terá efeito suspensivo e a repercussão geral será presumida no caso de recurso extraordinário (art. 987, $\S 1^{\circ}$, do NCPC). A decisão pelo tribunal superior será aplicada a todos os processos individuais e coletivos do território nacional (art. 987 , $\S 2^{\circ}$, do NCPC).

A tese jurídica decidida no incidente poderá ser revista, de ofício ou a requerimento do Ministério Público ou da Defensoria Pública, pelo mesmo tribunal que a fixou (art. 986, do NCPC). Ao apreciar a alteração da tese, o tribunal poderá designar audiência pública, permitir a participação de pessoas ou entidades interessadas na questão, modular os efeitos da alteração do entendimento quando houver interesse social e para garantir a segurança jurídica, e a decisão deverá considerar os princípios da segurança jurídica e isonomia (art. 927, $\S 2^{\circ}$ a $4^{\circ}$, do NCPC). Aplicam-se as demais regras do procedimento da fixação da tese para sua revisão, como a suspensão dos processos sobre a mesma questão de direito e ampla divulgação.

\subsubsection{Recursos especial e extraordinário repetitivos}

Como vimos anteriormente, o processo-modelo para apreciação dos recursos especial e extraordinário repetitivos, respectivamente, pelo Superior Tribunal de Justiça e Supremo Tribunal Federal, existiam na vigência do Código de Processo Civil de 1973 como mecanismo para tratar de questões de direitos idênticas reiteradas em inúmeros recursos.

Quando houver multiplicidade de recursos extraordinário ou especial sobre a mesma questão de direito, o presidente ou vice-presidente do tribunal local poderá requerer a afetação da tese e selecionar dois ou mais recursos representativos da controvérsia para serem remetidos aos tribunais superiores - que poderá selecionar outros

52 TALAMINI, Eduardo. A dimensão coletiva ... cit., p. 124-125.

53 O amicus curiae não tem legitimidade para interpor recurso porque não tem interesse próprio (MENDES, Aluisio Gonçalves de Castro; TEMER, Sofia. O incidente de resolução ... cit., p. 616-617). 
recursos (art. 1.036, $\S 4^{\circ}$, do $\mathrm{NCPC}$ ) -, bem como determinará a suspensão de todos os processos individuais e coletivos pendentes que tramitarem no seu Estado ou região ${ }^{54}$ (art. 1.036, $\S 1^{\circ}$, do NCPC). O tribunal superior poderá indeferir a afetação, devendo comunicar o presidente ou vice-presidente do tribunal local para revogar a suspensão dos processos (art. 1.037, § $1^{\circ}$, do NCPC).

O relator do tribunal superior também poderá determinar a afetação da questão e selecionar dois ou mais recursos representativos da controvérsia (art. 1.036, $\S$ $5^{\circ}$, do NCPC). É importante ressaltar que o Código traz critério genérico para seleção do recurso-modelo, que é a argumentação e discussão abrangente sobre a questão que será decidida (art. 1.036, § $6^{\circ}$, do NCPC).

O relator competente do tribunal superior para decidir a questão de direito deverá identificá-la precisamente, determinar a suspensão de todos os processos que tramitam no território nacional e requisitar a remessa de recursos aos tribunais inferiores (art. 1.037, I, II e III, do NCPC). Os recursos representativos da controvérsia que tratarem de outras questões deverão ser parcialmente apreciados para que seja decidida a matéria de direito não afetada (art. 1.037, § $7^{\circ}$, do NCPC).

A suspensão dos processos será comunicada às partes pelo juízo ou relator competente de cada processo, que poderão alegar que a questão a ser decidida não tem relação com a tese que será apreciada em recurso repetitivo. A parte contrária deverá ser intimada e o juiz ou relator competente poderá reconhecer a distinção para determinar o prosseguimento do processo. A decisão que reconhecer ou afastar a distinção poderá ser impugnada pela parte interessada (art. 1.037, $\S 9^{\circ}$ a $13^{\circ}$, do NCPC).

As pessoas, órgãos ou entidades interessados na controvérsia poderão se manifestar. O relator poderá designar audiência pública para ouvir pessoas com experiência ou conhecimento na matéria. O Ministério Público deverá ser intimado para se manifestar (art. 1.038, I, II e III, do NCPC).

Os processos afetados deverão ser decididos e os demais que tramitarem perante as Cortes Superiores serão considerados prejudicados. É possível que não seja reconhecida a repercussão geral do recurso extraordinário afetado e os demais recursos sobre a mesma questão não serão admitidos (art. 1.039, do NCPC).

Os recursos especial e extraordinário pendentes no tribunal local terão seu seguimento negado se o acórdão recorrido esteja em conformidade com a decisão do tribunal superior. Caso contrário, o processo será remetido ao órgão que proferiu o acórdão recorrido para reexaminar o recurso, remessa necessária, ou processo de sua

\footnotetext{
$54 \quad$ A parte interessada poderá requerer que os recursos intempestivos não sejam admitidos. A parte contrária deverá ser ouvida e da decisão que não reconhecer a intempestividade caberá agravo (art. $1.036, \S \S 2^{\circ}$ e $3^{\circ}$, do NCPC).
} 
competência originária (art. 1.040, I e II, do NCPC). Se a decisão for mantida, o recurso deverá ser remetido ao tribunal superior (art. 1.041, caput, do NCPC). Caso o recurso especial ou extraordinário trate de outras questões que não foram objeto da tese fixada, o tribunal deverá remetê-lo ao tribunal superior (art. 1.041, § $2^{\circ}$, do NCPC). Os processos que tramitarem em primeira e segunda instâncias prosseguirão com aplicação da tese firmada (art. 1.040, III, do NCPC). ${ }^{55}$

O tribunal superior deverá julgar o processo afetado no prazo de um ano; após esse período os processos suspensos retomarão seu regular andamento. No entanto, é possível que outro relator do respectivo tribunal afete a mesma questão em outros dois ou mais recursos e, consequentemente, novamente os processos sejam suspensos (art. $1.037, \S \S 5^{\circ}$ e $6^{\circ}$, do NCPC). Reitera-se a necessidade de observância do prazo sob pena de negativa de acesso à justiça. ${ }^{56}$

O tribunal superior poderá alterar seu entendimento sobre a tese fixada, podendo ouvir as pessoas interessadas na questão e designar audiência pública para permitir a participação da sociedade. A decisão que alterar o entendimento poderá prever a modulação dos efeitos quando for necessário para atender o interesse social e a segurança jurídica, bem como deverá considerar os princípios da segurança jurídica e isonomia (art. 927, $\S \S 2^{\circ} \mathrm{a} 4^{\circ}$ ). O Código não prevê os demais requisitos para alteração da tese, mas se pode adotar o mesmo procedimento para afetação do recurso, como a suspensão dos recursos pendentes.

\subsubsection{Incidente de assunção de competência}

O incidente de assunção de competência poderá ser suscitado pelo relator, partes, Ministério Público ou Defensoria Pública quando o recurso, remessa necessária ou processo de competência originária tratar de questão de direito relevante, com grande repercussão social, mas que não se repete em múltiplos recursos, para que seja apreciado pelo órgão colegiado indicado no regimento (art. 947, caput e $\S 1^{\circ}$, do NCPC).

$\mathrm{O}$ órgão colegiado deverá apreciar a existência do interesse público. Caso entenda que está presente, não implicará em suspensão dos processos sobre a mesma questão e a decisão será vinculante a todos os juízes inferiores e órgãos fracionários do tribunal, salvo se a tese for revista (art. 947, $\S \S 2^{\circ}$ e $3^{\circ}$, do NCPC). O Código é omisso quanto à revisão da tese, devendo-se adotar o mesmo procedimento para sua fixação.

\footnotetext{
55 Quando o processo tramitar em primeiro grau de jurisdição, o autor poderá desistir da ação independentemente do consentimento do réu. Se a desistência ocorrer antes da contestação, a parte ficará isenta do pagamento de custas, honorários de sucumbência (art. 1.040, $\S 1^{\circ}$ a $3^{\circ}$, do NCPC).

56 MAZZILLI, Hugo Nigro. O processo coletivo ... cit., p. 197.
} 
O mesmo procedimento deverá ser adotado para evitar ou superar divergência entre câmaras e turmas do tribunal sobre relevante questão de direito (art. $947, \S 4^{\circ}$, do NCPC).

\section{Tutela coletiva de direitos e suas limitações}

Segundo definição consolidada no Código de Defesa do Consumidor, os interesses coletivos lato sensu são: a) difusos "de natureza indivisível, de que sejam titulares pessoas indeterminadas e ligadas por circunstâncias de fato"; b) coletivos stricto sensu "de natureza indivisível de que seja titular grupo, categoria ou classe de pessoas ligadas entre si ou com a parte contrária por uma relação jurídica base"; e c) individuais homogêneos "decorrentes de origem comum" (art. 81, par. único, I a III, da Lei n. $8.078 / 1990) .{ }^{57}$

O direito brasileiro dispõe de diversos instrumentos para solução do litígio coletivo. De um lado, são cabíveis as ações coletivas para tutelar diferentes tipos de interesses coletivos lato sensu. As ações de controle concentrado de constitucionalidade tutelam interesse difuso de afastar lei, ato normativo ou interpretação contrários à Constituição Federal.

Destacamos que os interesses individuais homogêneos, na verdade, são direitos individuais tratados coletivamente para que a decisão do conflito seja mais eficiente. $\mathrm{O}$ direito brasileiro tem sistema avançado de tutela coletiva desses direitos, que permite o tratamento uniforme de interesses metaindividuais para evitar a multiplicação de ações individuais sobre a mesma questão e decisões conflitantes. ${ }^{58}$

No entanto, veremos que a sistemática para tutela coletiva de direitos não é suficiente para tratar todos os litígios de massa devido às limitações impostas pela lei. A última tentativa de aprimorar as ações coletivas, por meio do Projeto de Lei n. 5.139/2009, foi arquivada porque "incomodava os governantes e parlamentares, com

$57 \quad$ A classificação legal é criticada porque não levaria em consideração os titulares do direito. Edilson Vitorelli propõe nova classificação dos direitos coletivos da seguinte forma: a) litígios transindividuais de dimensão global "a lesão não atinge diretamente os interesses de qualquer pessoa", por exemplo, vazamento de óleo, em pequena quantidade, no oceano. Esses direitos atingem a sociedade como um todo (VITORELLI, Edilson. Tipologia dos litígios transindividuais: um novo ponto de partida para a tutela coletiva. In: ZANETI JR., Hermes (Coord.). Processo coletivo. Salvador: Juspodivm, 2016. (Coleção repercussões do novo CPC, v. 8). p. 89-91); b) direitos transindividuais de difusão local em que a violação de direito atinge gravemente determinado grupo (Idem, p. 93); c) litígios transindividuais de difusão irradiada, cuja lesão "afeta diretamente os interesses de diversas pessoas ou segmentos sociais, mas essas pessoas não compõem uma comunidade, não têm a mesma perspectiva social e não serão atingidas, na mesma medida, pelo resultado do litígio, o que faz com que suas visões antagônicas acerca de seu resultado desejável sejam divergentes e, não raramente, antagônicas.” (Id. Ibid., p. 97). Embora a nova classificação seja coerente, adotaremos aquela que está consagrada na doutrina dos processos coletivos e na legislação brasileira.

58 MANCUSO, Rodolfo de Camargo. Divergência jurisprudencial ... cit., p. 485. 
as ações de improbidade administrativa; incomodava os empresários, com as ações de responsabilidade civil, as ações ambientais e as de defesa do consumidor; incomodava, enfim, os poderosos.". 59

\subsection{Ações coletivas}

\subsubsection{Ação popular}

A Constituição Imperial de 1824 já previa a ação popular, que foi progressivamente ampliada e aprimorada ao longo dos últimos anos. A Constituição de 1988 lhe atribuiu especial relevância para prever seu cabimento para tutelar a moralidade administrativa, o meio ambiente e o patrimônio histórico e cultural (art. $5^{\circ}$, LXIII, da $\mathrm{CF} / 88)$.

A legitimidade para propor a ação popular é limitada ao cidadão (art. $5^{\circ}$, LXIII, da CF/88), podendo outro cidadão atuar como assistente ou litisconsorte do autor (art. $6^{\circ}, \S 5^{\circ}$, da Lei n. 4.717/1965).

O objeto da ação popular é a anulação de ato administrativo ilegal ou contrário à moralidade administrativa (arts. $2^{\circ} \mathrm{a} 4^{\circ}$, da Lei n. 4.717/1965). Assim, somente os interesses coletivos violados por ato administrativo podem ser impugnados por meio de ação popular, podendo um cidadão litigar em face do Poder Público.

A sentença da ação popular é restrita à anulação do administrativo impugnado e ressarcimento do dano ao autor da demanda (art. 11, da Lei n. 4.717/1965) e não aos demais interessados e prejudicados pelo mesmo ato. Por isso, a ação popular não tutela amplamente os direitos coletivos.

\subsubsection{Ação civil pública}

A ação civil pública é instrumento por excelência para tutela dos interesses coletivos lato sensu, pois prevê legitimidade do Ministério Público, associação civil, entes federativos, autarquia, empresa pública, fundação, sociedade de economia mista e Defensoria Pública (art. 5 ${ }^{\circ}$ caput, I a V, da Lei n. 7.347/1985).

No entanto, após as ações civis públicas começarem a incomodar determinados interesses políticos, tentou-se criar obstáculo para atuação da associação ao se exigir que ela deveria instruir a petição inicial com a ata de assembleia que autorizou o seu ajuizamento e relação de todos os associados com seus endereços (art. $2^{\circ}$ - A da Lei n. 9.494/1997 pela Medida Provisória n. 2.180-35/2001). O legislador confundiu a

59 $\quad$ MAZZILLI, Hugo Nigro. O processo coletivo ... cit., p. 186. 
representação com substituição processual, nesse último caso não é necessária autorização específica quando a ação é compatível com a sua finalidade institucional. ${ }^{60}$

A lei veda o ajuizamento de ação civil pública para tratar de relevantes interesses individuais homogêneos: tributos, contribuições previdenciárias, Fundo de Garantia do Tempo de Serviço - FGTS e outros fundos de natureza institucional (art. $1^{\circ}$, par. único, da Lei n. 7.347/1985, introduzido pela Medida provisória n. 2.180-35/2001).

A disciplina da coisa julgada na ação civil pública foi alterada pela Lei n. 9.494/1997 para prever a restrição da coisa julgada aos limites territoriais do órgão prolator da decisão, confundindo competência com eficácia da sentença. Além disso, a decisão em ação civil pública ajuizada por associação vincularia apenas os associados que tinham residência no âmbito da sua competência territorial na data do ajuizamento da demanda (art. $2^{\circ}$-A, caput, da Lei n. 9.494/1997). ${ }^{61}$

Por fim, o art. 94 do Código de Defesa do Consumidor determina a publicidade apenas da interposição da ação civil pública por meio da publicação de edital por órgão oficial, sem prejuízo de comunicação por outros meios. A sentença sobre a ação civil pública também deveria ser amplamente divulgada para permitir a ciência dos interessados. $^{62}$

\subsubsection{Mandado de segurança coletivo}

O mandado de segurança coletivo foi introduzido pela Constituição Federal de 1988, representando uma das inovações mais relevantes na tutela coletiva de direitos. O mandamus pode ser impetrado por partido político com representação no Congresso Nacional, organização sindical, entidade de classe, ou associação legalmente constituída há pelo menos um ano na defesa dos interesses dos seus membros ou associados (art. $5^{\circ}$, LXX, da CF/88).

Somente depois de mais de 20 anos da promulgação da Constituição, o mandado de segurança coletivo passou a ter disciplina legal, que buscou restringir seu cabimento. A lei limitou a legitimidade dos partidos políticos para defesa dos

60 LEONEL, Ricardo de Barros. Manual do processo coletivo. 3. ed. São Paulo: Revista dos Tribunais, 2013. p. 167.

${ }^{61}$ A limitação dos efeitos da coisa julgada sofreu inúmeras críticas, dentre as quais destacamos o possível conflito lógico e prático de julgados sobre a mesma situação (LEONEL, Ricardo de Barros. Manual do processo coletivo ... cit., p. 305-307). Acrescenta-se que a previsão legal é ineficaz porque o art. 103 do Código de Defesa do Consumidor prevê que a coisa julgada produz efeitos erga omnes quando tratar de interesse difuso e individual homogêneo e ultra partes para interesse coletivo stricto sensu, sem limitação territorial.

62 GAJARDONI, Fernando da Fonseca. O processo coletivo refém do individualismo. In: ZANETI JR., Hermes (Coord.). Processo coletivo. Salvador: Juspodivm, 2016. (Coleção repercussões do novo CPC, v. 8). p. 145-146. 
interesses relativos a seus integrantes ou à finalidade partidária (art. 21, caput, da Lei n. 12.016/2009). ${ }^{63}$ Além disso, o parágrafo único do referido artigo prevê o seu cabimento apenas para tutela dos direitos coletivos stricto sensu e individual homogêneo, ${ }^{64}$ afastando implicitamente a impetração do mandamus para tutela de direito difuso. ${ }^{65}$

A nova lei também restringiu os efeitos da coisa julgada aos membros do grupo ou categoria substituído pelo impetrante, desde que tenham desistido do eventual mandado de segurança individual impetrado (art. 22, caput e $\S 1^{\circ}$, da Lei n. 12.016/2009). ${ }^{66}$ A sistemática não observa as regras previstas para a ação civil pública, que estendem os efeitos da coisa julgada para ação individual se o interessado requerer a sua suspensão, podendo prosseguir com a demanda em caso de improcedência do processo coletivo (art. 104, da Lei n. 8.078/1990).

Além das limitações acima mencionadas, o mandado de segurança tem cabimento restrito para lesão ou ameaça de lesão a direito líquido e certo por autoridade. Assim, somente o interesse coletivo líquido e certo poderia ser tutelado por meio do mandado de segurança.

63 A limitação é incompatível com o texto constitucional, que não exige a pertinência temática (ZAVASCKI, Teori Albino. O mandado de segurança coletivo na Lei n. 12.016/2009. In: MILARÉ, Édis (Coord.). A ação civil pública após 25 anos. São Paulo: Revista dos Tribunais, 2010. p. 791). Além disso, os partidos políticos não são criados para defesa de interesses dos seus filiados, mas para tutela dos interesses definidos no seu programa partidário. Como o mandado de segurança é um remédio constitucional, ele deve ser aplicado e interpretado para dar a mais ampla eficácia (GRINOVER, Ada Pellegrini. Mandado de segurança coletivo: legitimação e objeto. Revista de Direito Público, São Paulo, v. 23, n. 93, p. 18-22, jan./mar. 1990. p. 21). No entanto, os tribunais superiores adotam o entendimento previsto na lei mesmo antes da sua promulgação (LEONEL, Ricardo de Barros. Manual do processo coletivo ... cit., p. 462).

${ }_{64}$ É cabível mandado de segurança coletivo para tutela de interesse difuso previsto no Estatuto da Criança e do Adolescente (art. 212, §2 $2^{\circ}$, da Lei n. 8.069/1990) (FERRARESI, Eurico. Do mandado de segurança: comentários à Lei 12.016, de 07 de agosto de 2009. Rio de Janeiro: Forense, 2010. p. 113-114).

${ }^{65}$ A restrição legal é indevida porque a Constituição admite amplamente o cabimento do mandado de segurança coletivo (LEONEL, Ricardo de Barros. Manual do processo coletivo ... cit., p. 452-453). Mesmo antes da lei, parte da doutrina defendia o cabimento do mandado de segurança coletivo para tutela de todos os tipos de direito coletivo (BARBI, Celso Agrícola. Do mandado de segurança. 8. ed. Rio de Janeiro: Forense, 1998. p. 293). De outro lado, alguns doutrinadores afirmam que não seria cabível porque o direito deve ser líquido e certo, que seria incompatível com a natureza do direito difuso (CARNEIRO, Athos Gusmão. Anotações sobre o mandado de segurança coletivo, nos termos da Lei n. 12.016/09. In: THEODORO JÚNIOR, Humberto; LAUAR, Maira Terra (Coord.). Tutelas diferenciadas como meio de incrementar a efetividade da prestação jurisdicional. Rio de Janeiro: GZ, 2010. p. 390-392). Confunde-se liquidez e certeza do direito com a titularidade indeterminada. É possível ajuizar mandado de segurança para tutela do direito difuso ao meio ambiente para, por exemplo, requerer a anulação de licença ambiental se a autoridade competente não convocou audiência pública requerida pelo Ministério Público ou por mais de cinquenta cidadãos (ALMEIDA, Ursula Ribeiro de. Tutela de urgência no direito ambiental: instrumento de efetivação do princípio da precaução. São Paulo: Atlas, 2015. p. 145).

${ }_{66}$ A decisão que apreciar direito difuso produzirá efeitos erga omnes, pois seus titulares são indeterminados e o direito é indivisível. No exemplo na nota anterior, a anulação da licença concedida produzirá efeitos erga omnes, devendo ser considerada inválida para aqueles que não integraram o mandado de segurança. 


\subsubsection{Incidente de conversão da ação individual em coletiva vetada no NCPC}

\section{$\mathrm{O}$ art. 333 do Novo Código de Processo Civil tratava de importante} instrumento para tutela coletiva de direitos, mas foi vetado pela Presidência da República. O referido dispositivo permitiria a conversão da ação individual em coletiva cujo objeto afetasse interesse coletivo stricto sensu e difuso, ou tratasse de litisconsórcio unitário facultativo, desde que houvesse relevante interesse social e dificuldade na formação de litisconsórcio. A conversão poderia ser requerida pelo Ministério Público, Defensoria Pública ou demais legitimados para ajuizar ação civil pública. ${ }^{67}$

Aconversão não seria cabível para tutela de direitos individuais homogêneos, após o início da audiência de instrução e julgamento, se houvesse processo coletivo pendente com o mesmo objeto, ou se o juízo não tivesse competência para apreciar a ação coletiva. $^{68}$

Caso a conversão fosse deferida, o requerente poderia emendar ou aditar a petição inicial, o réu deveria ser intimado para apresentar defesa, o Ministério Público também deveria ser intimado se não fosse o requerente da conversão, o autor originário da demanda prosseguiria na demanda como litisconsorte ativo e o processo deveria observar o procedimento do processo coletivo. Se houvesse outro pedido de natureza estritamente individual, esse deveria ser apreciado em autos apartados. ${ }^{69}$

67 "Art. 333. Atendidos os pressupostos da relevância social e da dificuldade de formação do litisconsórcio, o juiz, a requerimento do Ministério Público ou da Defensoria Pública, ouvido o autor, poderá converter em coletiva a ação individual que veicule pedido que:

I - tenha alcance coletivo, em razão da tutela de bem jurídico difuso ou coletivo, assim entendidos aqueles definidos pelo art. 81, parágrafo único, incisos I e II, da Lei n. 8.078, de 11 de setembro de 1990 (Código de Defesa do Consumidor), e cuja ofensa afete, a um só tempo, as esferas jurídicas do indivíduo e da coletividade;

II - tenha por objetivo a solução de conflito de interesse relativo a uma mesma relação jurídica plurilateral, cuja solução, por sua natureza ou por disposição de lei, deva ser necessariamente uniforme, assegurando-se tratamento isonômico para todos os membros do grupo.

$\S 1^{\circ}$ Além do Ministério Público e da Defensoria Pública, podem requerer a conversão os legitimados referidos no art. $5^{\circ}$ da Lei n. 7.347, de 24 de julho de 1985, e no art. 82 da Lei n. 8.078, de 11 de setembro de 1990 (Código de Defesa do Consumidor)."

68 “Art. $333[\ldots] \S 2^{\circ}$ A conversão não pode implicar a formação de processo coletivo para a tutela de direitos individuais homogêneos.

$\S 3^{\circ}$ Não se admite a conversão, ainda, se:

I - já iniciada, no processo individual, a audiência de instrução e julgamento; ou

II - houver processo coletivo pendente com o mesmo objeto; ou

III - o juízo não tiver competência para o processo coletivo que seria formado."

69 " $§ 4^{\circ}$ Determinada a conversão, o juiz intimará o autor do requerimento para que, no prazo fixado, adite ou emende a petição inicial, para adaptá-la à tutela coletiva.

$\S 5^{\circ}$ Havendo aditamento ou emenda da petição inicial, o juiz determinará a intimação do réu para, querendo, manifestar-se no prazo de 15 (quinze) dias.

$\S 6^{\circ} \mathrm{O}$ autor originário da ação individual atuará na condição de litisconsorte unitário do legitimado para condução do processo coletivo. 
Ainda que o referido dispositivo legal tenha sido vetado, o instituto é relevante porque o art. 30 do Projeto de Lei n. 8.058/2014 (Lei de Controle Judicial de Políticas Públicas) prevê procedimento semelhante para permitir a conversão da ação individual em coletiva. ${ }^{70}$

O dispositivo legal foi vetado porque permitiria a conversão "de maneira pouco criteriosa" e o "o novo Código já contempla mecanismos para tratar das demandas repetitivas". ${ }^{71}$ Quanto à segunda fundamentação, vê-se que não se compreendeu que o instituto visava dar tratamento adequado para interesse coletivo objeto de ação individual, com a devida manifestação do Ministério Público e a extensão dos efeitos da coisa julgada. As demandas repetitivas, por sua vez, tratam de grande quantidade de demandas, sobre direitos individuais ou coletivos, em que há controvérsia sobre a mesma questão de direito.

Além das razões do veto, alguns entenderam que o referido instituto implicaria na negativa de acesso à justiça do autor individual, pois não teria a sua demanda apreciada. O referido dispositivo contraria a sistemática do processo coletivo brasileiro, que não obsta o ajuizamento de ação individual. ${ }^{72}$

De outro lado, argumenta-se que haveria ampliação do acesso à justiça porque a demanda individual seria apreciada e o autor originário atuaria como litisconsorte unitário, podendo praticar todos os atos do processo e ainda seria desonerado do pagamento de custas. Embora torne o processo mais complexo, a técnica seria legítima assim como outras que tornam o processo mais complexo em busca da efetividade, como as intervenções de terceiros e reconvenção. O mecanismo também teria coerência com

$\S 7^{\circ} \mathrm{O}$ autor originário não é responsável por nenhuma despesa processual decorrente da conversão do processo individual em coletivo.

$\S 8^{\circ}$ Após a conversão, observar-se-ão as regras do processo coletivo.

$\S 9^{\circ} \mathrm{A}$ conversão poderá ocorrer mesmo que o autor tenha cumulado pedido de natureza estritamente individual, hipótese em que o processamento desse pedido dar-se-á em autos apartados.

$\S 10$. O Ministério Público deverá ser ouvido sobre o requerimento previsto no caput, salvo quando ele próprio o houver formulado."

70 COSTA, Susana Henrique da. Morte e vida da conversão da ação individual em coletiva. In: GRINOVER, Ada Pellegrini et al. O novo código de processo civil: questões controvertidas. São Paulo: Atlas, 2015. p. 423-424.

71 "Da forma como foi redigido, o dispositivo poderia levar à conversão de ação individual em ação coletiva de maneira pouco criteriosa, inclusive em detrimento do interesse das partes. O tema exige disciplina própria para garantir a plena eficácia do instituto. Além disso, o novo Código já contempla mecanismos para tratar demandas repetitivas. No sentido do veto manifestou-se também a Ordem dos Advogados do Brasil - OAB." (Parecer da Advocacia-Geral da União, Veto Presidencial ao Projeto de Lei do Senado n. 166/2010 e da Câmara n. 8.046/2010).

72 TUCCI, José Rogério Cruz e. Paradoxo da corte. Um veto providencial ao novo Código de Processo Civil! Revista Consultor Jurídico, São Paulo, mar. 2015. Disponível em: <http://www.conjur.com.br/2015mar-17/paradoxo-corte-veto-providencial-cpc>. Acesso em: 25 maio 2016. 
nosso sistema que não admite tutela de direitos metaindividuais por legitimado individual, salvo na ação popular. ${ }^{73}$

Embora o referido instrumento para coletivização da demanda tenha sido vetado, o art. 139, X, do novo Código pode ser útil para tutela coletiva de direitos, pois determina a comunicação do Ministério Público, da Defensoria Pública, e - na medida do possível - dos demais legitimados para propor ação civil pública, quando houver diversas demandas repetitivas individuais. Os legitimados terão ciência da relevância da questão e poderão ajuizar a ação coletiva cabível. ${ }^{74}$

\subsection{Ações de controle concentrado de constitucionalidade}

As ações de controle concentrado de constitucionalidade, cuja competência para apreciação é do Supremo Tribunal Federal, são instrumentos para tutela dos direitos coletivos porque afastam norma ou interpretação incompatível com a ordem constitucional. ${ }^{75}$ São elas a ação direta de inconstitucionalidade, ação declaratória de constitucionalidade, ação direta de inconstitucionalidade por omissão e arguição de descumprimento de preceito fundamental.

No entanto, a sua utilização para tutela coletiva de direitos sofre diversas limitações, dentre as quais destacamos legitimidade restrita a determinados entes previstos na Constituição Federal (art. 103, caput, I a IX, da CF/88, e art. $2^{\circ}$, I, da Lei n. 9.882/1999), com exigência do requisito da pertinência temática para alguns deles pela jurisprudência do $\mathrm{STF}^{76}$

O objeto das ações de controle de constitucionalidade também é limitado para declaração da inconstitucionalidade, constitucionalidade, interpretação conforme, ou recepção de lei ou ato normativo abstrato (art. 102, I, “a”, CF/88). Na ação de declaratória de constitucionalidade deve ser demonstrada a relevância da controvérsia quanto à constitucionalidade da lei ou ato normativo impugnado (art. 14, III, da Lei n. 9.868/1999). A ação de descumprimento de preceito fundamental, por sua vez, tem caráter subsidiário, sendo admitida apenas quando não houver outro meio eficaz para sanar a lesividade (art. $4^{\circ}, \S 1^{\circ}$, da Lei n. 9.882/1999)..$^{77}$

\footnotetext{
COSTA, Susana Henrique da. Morte e vida ... cit., p. 436.

TALAMINI, Eduardo. A dimensão coletiva ... cit., p. 128-129.

ZAVASCKI, Teori Albino. Processo coletivo: tutela de direitos coletivos e tutela coletiva de direitos. 4. ed. São Paulo: Revista dos Tribunais, 2009. p. 241.

76 A Mesa da Assembleia Legislativa ou a Câmara Legislativa do Distrito Federal, os Governadores, as confederações sindicais e entidades de âmbito nacional devem demonstrar o requisito da pertinência temática (DIMOULIUS, Dimitri; LUNARDI, Soraya. Curso de processo constitucional: controle de constitucionalidade e remédios constitucionais. São Paulo: Atlas, 2011. p. 103).

77 A ação não é cabível quando outra puder ser ajuizada, com efeitos erga omnes e vinculantes, para superar a
} 
5. Eficácia vinculante dos precedentes do processo-modelo $v$. ações coletivas e de controle concentrado de constitucionalidade

A eficácia vinculante dos precedentes no processo-modelo visa solucionar conjuntamente multiplicidade de ações e recursos sobre a mesma questão de direito, que pode ser relativo a direito coletivo ou individual, direito material ou processual. As ações de controle concentrado de constitucionalidade se limitam a questão de direito constitucional. De outro lado, as ações coletivas permitem a solução da mesma questão de fato e de direito relativa a grupo, determinado ou determinável, de pessoas, em que pode haver ou não multiplicidade de processos.

O julgamento por meio da técnica do processo-modelo soluciona de forma mais ampla as demandas repetitivas sobre questão de direito, pois não se restringe aos direitos coletivos e também podem tratar de matéria constitucional ou infraconstitucional. No entanto, as ações coletivas solucionam de maneira mais ampla os litígios sobre direitos coletivos porque permitem a apreciação de fatos e do direito.

Os precedentes vinculantes no processo-modelo implicam na suspensão de todos os processos sobre a mesma questão de direito, enquanto a ação coletiva não suspende as ações individuais e as ações de controle de constitucionalidade somente suspendem se houver decisão do STF por maioria de votos em sede de medida cautelar (arts. 10, caput, 11, 12-F e 21, todos da Lei n. 9.868/1999). A suspensão é vantajosa por garantir a aplicação da mesma interpretação para todos os processos, mas pode ser prejudicial porque obsta o julgamento dos processos por prazo legal extenso, que pode ser prorrogado ainda mais por decisão do tribunal.

A representatividade adequada nos processos coletivos é garantida por meio da previsão legal dos legitimados ativos, sempre com a intervenção do Ministério Público como fiscal da lei. Já no processo-modelo, o controle da representatividade é feito exclusivamente pelo Tribunal competente para julgá-lo, sem possibilidade sequer de os interessados indicarem um recurso com maior abrangência dos argumentos, como ocorre no direito alemão.

Embora a representatividade adequada tenha controle deficiente no processo-modelo, a decisão tem efeitos vinculantes para todos os processos pendentes e futuros, ou seja, mesmo para aqueles que não tiveram sequer oportunidade para apresentarem outros argumentos sobre a questão de direito. ${ }^{78}$ Por um lado, a ampla

divergência jurisprudencial (STF, Pleno, ADPF N. 33/PA, relator Ministro Gilmar Mendes, j. 07/12/2005, DJ 27/10/206, p. 31).

78 Vimos que no direito alemão, a decisão do processo-modelo vincula apenas as partes das demandas pendentes de julgamento. 
vinculação propicia a redução do número de processos, mas também é questionável devido à falta de possibilidade de participação dos interessados na questão. Nas ações de controle de constitucionalidade, a eficácia vinculante é ainda mais ampla porque a decisão que declara a inconstitucionalidade produz coisa julgada com eficácia erga omnes.

O processo coletivo, por sua vez, garante o maior acesso à justiça porque a decisão faz coisa julgada e produz efeitos vinculantes para beneficiar a coletividade. Caso contrário, não obsta o prosseguimento ou o ajuizamento de ação individual sobre a matéria objeto de ação coletiva julgada improcedente.

Pode haver sobreposição das diferentes técnicas quando houver ampla divergência sobre questão de direito coletivo do qual não caiba ação de controle concentrado de constitucionalidade. Como a ação coletiva não obsta o ajuizamento de ação individual sobre a mesma questão de direito, ela não solucionaria o problema da multiplicidade de processos, cuja tese poderá ser fixada em processo-modelo e se aplicar a todos os processos pendentes. O processo-modelo pode ser útil também nas hipóteses em que a ação coletiva cabível não foi ajuizada pelos legitimados legais e há multiplicidade de processos individuais sobre a mesma questão de direito.

De outro lado, as ações coletivas suprem a limitação do processo-modelo na medida em que algumas violações de direitos coletivos não são questionadas em diversas demandas individuais, como, por exemplo, violação a direitos individuais homogêneos de pequena monta, direito da minoria e direito ambiental.

\section{Conclusão: eficácia vinculante dos precedentes como tutela coletiva de direitos}

A tutela coletiva de direitos visa conferir proteção a interesses supraindividuais e pulverizados de forma célere, isonômica e com segurança jurídica. ${ }^{79} \mathrm{O}$ direito brasileiro tradicionalmente tutela os interesses transindividuais por meio das ações coletivas e das ações de controle concentrado de constitucionalidade.

Ocorre que esses mecanismos não são suficientes para tutela dos interesses coletivos, já que a legislação impõe restrições aos legitimados e à matéria que podem ser objeto das referidas ações. De outro lado, multiplicaram-se nas últimas décadas os processos individuais sobre a mesma questão de direito, especialmente perante os tribunais superiores. Para lidar com a litigiosidade de massa, o novo Código de Processo Civil ampliou e aprimorou o julgamento dos processos-modelo. ${ }^{80}$

\footnotetext{
79 DURÇO, Karol Araújo. As soluções para demandas repetitivas no novo Código de Processo Civil e suas implicações para o processo coletivo. In: ZANETI JR., Hermes (Coord.). Processo coletivo. Salvador: Juspodivm, 2016. (Coleção repercussões do novo CPC, v. 8). p. 532.

${ }^{80}$ LEONEL, Ricardo de Barros. Intervenção do Ministério Público ... cit., p. 176-177.
} 
Assim, pode-se afirmar que o IRDR, os recursos especial e extraordinário repetitivos e incidente de assunção de competência integram o sistema de tutela coletiva de direitos na medida em que permitem a aplicação da mesma tese jurídica em multiplicidade de casos similares. ${ }^{81}$ Os referidos mecanismos também permitem a solução de inúmeras ações individuais sobre direito coletivo que não podem ser tutelados por ação coletiva, ${ }^{82}$ quando esta não for adequada ${ }^{83}$ ou mesmo se houver multiplicidade de ações coletivas sobre a mesma questão. ${ }^{84}$

Para dar efetividade às decisões proferidas no processo-modelo, o novo Código adotou diversos mecanismos para tornar o precedente vinculante, cujo objetivo é inviabilizar o prosseguimento da demanda ou recurso contra tese fixada pelo tribunal. Nesse sentido, observa-se maior proximidade do novo modelo processual brasileiro do sistema da Commom Law, cujo objetivo é reduzir o número de demandas e tornar a ordem jurídica mais coerente.

A técnica do processo-modelo em sede recursal não implica em esvaziamento das demais tutelas coletivas de direito. A lei, o ato normativo, ou a interpretação de lei ou ato normativo inconstitucional somente podem ser excluídos da ordem jurídica por meio das ações de controle concentrado de constitucionalidade. Os danos aos direitos individuais homogêneos de pequena monta, aos direitos da minoria, ao direito ao meio ambiente, dentre outros, somente podem ser tutelados adequadamente pela ação coletiva, já que não há interesse ou legitimidade para tutela em ação individual..$^{85}$

O processo-modelo deve ser usado como complemento das ações coletivas para, por exemplo, aplicar o mesmo cadastro público para divulgação da tese afetada. No entanto, ele não pode ser usado para substituir as ações coletivas, já que elas têm controle mais rigoroso da representatividade adequada, são analisados os fatos relevantes para controvérsia, a decisão produz coisa julgada com efeitos erga omnes ou ultra partes ${ }^{86}$ para

81 LUCON, Paulo Henrique dos Santos. Relação entre demandas ... cit., p. 213.

82 Ações previstas no art. $1^{\circ}$, parágrafo único, da Lei n. $7.347 / 1985$, por exemplo.

83 A tutela dos direitos individuais homogêneos via ação coletiva somente se justifica se for mais eficaz que a ação individual. Se a liquidação da decisão coletiva é tão complexa quanto ação condenatória individual, vêse que a tutela coletiva não se mostra adequada (GRINOVER, Ada Pellegrini. O processo. II série: estudos e pareceres de processo civil. Brasília: Gazeta Jurídica, 2013. p. 88-89).

84 ROQUE, Andre Vasconcelos. As ações coletivas após o novo Código de Processo Civil: para onde vamos? ZANETI JR., Hermes (Coord.). Processo coletivo. Salvador: Juspodivm, 2016. (Coleção repercussões do novo CPC, v. 8). p. 163-171.

85 MENDES, Aluisio Gonçalves de Castro; SILVA, Larissa Clare Pochmann da. Ações coletivas e incidente de resolução de demandas repetitivas: algumas considerações sobre a solução coletiva de conflitos. In: ZANETI JR., Hermes (Coord.). Processo coletivo. Salvador: Juspodivm, 2016. (Coleção repercussões do novo CPC, v. 8). p. 545-548.

86 "A coisa julgada, como técnica de proteção da segurança jurídica, tem mais força do que respeito aos precedentes. O precedente é destinado a garantir a estabilidade da aplicação do direito, enquanto a coisa julgada garante a inalterabilidade da aplicação do direito em determinado caso concreto. Ao contrário do 
beneficiar a coletividade e a ação coletiva não obsta o andamento de ação individual ${ }^{87}$ No processo-modelo, por sua vez, a escolha do caso-piloto é feita pelo tribunal sem critérios legais claros, examina-se apenas a questão de direito, implica na suspensão dos processos individuais e coletivos e a decisão é vinculante para toda coletividade.

Não podemos deixar de alertar que a adoção do processo-modelo para solucionar litígios de massa deve ser criteriosa para não favorecer os litigantes habituais. Eles poderão obter a fixação da tese jurídica favorável em um único processo em que a escolha do processo-modelo representativo da controvérsia não é clara, cuja decisão vinculará todos os processos pendentes e futuros; enquanto na ação coletiva precisam atuar em face do Ministério Público ou outro legitimado e a decisão não prejudica os litigantes individuais. ${ }^{88}$

São Paulo, abril de 2016.

\section{Referências}

ACT on model case proceedings in disputes under capital markets law. Translation provided by Jane Yager for the Federal Ministry of Justice and Consumer Protection. Disponível em: <http://www. gesetze-im-internet.de/englisch_kapmug/englisch_kapmug.pdf>. Acesso em: 12 abr. 2016.

ALMEIDA, Ursula Ribeiro de. Tutela de urgência no direito ambiental: instrumento de efetivação do princípio da precaução. São Paulo: Atlas, 2015.

ANDREWS, Neil H. Multi-party litigation in England. Legal Studies Research Paper Series, Cambridge, n. 39, p. 1-15, set./2013.

BAETGE, Dietmar. Class actions, group litigation \& other forms of collective litigation: Germany. Global Class Actions Exchange, Stanford, 2007. Disponível em: $<$ http://globalclassactions.stanford. edu/sites/default/files/documents/Germany_National_Report.pdf>. Acesso em: 25 maio 2016.

BARBI, Celso Agrícola. Do mandado de segurança. 8. ed. Rio de Janeiro: Forense, 1998.

que ocorre em relação à coisa julgada, a estabilidade garantida pelo precedente não é absoluta, na medida em que os precedentes podem ser revogados. O judiciário pode deixar de interpretar a lei em sentido, mas a interpretação da lei, cristalizada em sentença acobertada pela coisa julgada, jamais poderá ser alterada de modo a roubar o benefício outorgado àquele que obteve a tutela jurisdicional do direito." (MARINONI, Luiz Guilherme. Precedentes obrigatórios ... cit., p. 140).

87 Na ação coletiva, é cabível a suspensão da ação individual "depende de uma avaliação de conveniência do interessado, que pode estar com seu processo individual em fase em que não lhe pareça oportuna ou desejável a suspensão" (MAZZILLI, Hugo Nigro. O processo coletivo ... cit., p. 197).

88 RODRIGUES, Marcelo Abelha. Técnicas individuais de repercussão coletiva x técnicas coletivas de repercussão individual. Por que estão extinguindo a ação civil pública para a defesa de direitos individuais homogêneos? In: ZANETI JR., Hermes (Coord.). Processo coletivo. Salvador: Juspodivm, 2016. (Coleção repercussões do novo CPC, v. 8). p. 634-635. 
BASCHIERA, Marinella. Introduction to the Italian legal system. The allocation of normative powers: issues in law finding. International Journal of Legal Information, Ann Arbor, v. 34, n. 2, p. 279-326, Summer 2006.

CAPELLETTI, Mauro; GARTH, Bryant. Acesso à justiça. Trad.: Ellen Gracie Northfleet. Porto Alegre: Sergio Antonio Fabris, 1988.

CAVALCANTI, Marcos de Araújo. A falta de controle judicial da adequação da representatividade no Incidente de Resolução de Demandas Repetitivas (IRDR). Revista Pensamento Jurídico, São Paulo, v. 7, n. 1, p. 30-47, 2015.

DIDIER JR., Fredie et al (Coord.). Precedentes. Salvador: Juspodivm, 2015. v. 3. (Coleção grandes temas do novo CPC).

DIMOULIUS, Dimitri; LUNARDI, Soraya. Curso de processo constitucional: controle de constitucionalidade e remédios constitucionais. São Paulo: Atlas, 2011.

DINAMARCO, Cândido Rangel. Instituições de direito processual civil. 8. ed. São Paulo: Malheiros, 2016. v. 1.

FERRARESI, Eurico. Do mandado de segurança: comentários à Lei 12.016, de 07 de agosto de 2009. Rio de Janeiro: Forense, 2010.

GRINOVER, Ada Pellegrini. Mandado de segurança coletivo: legitimação e objeto. Revista de Direito Público, São Paulo, v. 23, n. 93, p. 18-22, jan./mar. 1990.

GRINOVER, Ada Pellegrini. O processo. II série: estudos e pareceres de processo civil. Brasília: Gazeta Jurídica, 2013.

GRINOVER, Ada Pellegrini et al. O novo código de processo civil: questões controvertidas. São Paulo: Atlas, 2015.

LEONEL, Ricardo de Barros. Intervenção do Ministério Público no incidente de resolução de demandas repetitivas. Revista Jurídica da Escola Superior do Ministério Público de São Paulo, São Paulo, v. 1, p. 173-185, 2012.

LEONEL, Ricardo de Barros. Manual do processo coletivo. 3. ed. São Paulo: Revista dos Tribunais, 2013.

LUCON, Paulo Henrique dos Santos. Relação entre demandas. Tese (Livre Docência) - Faculdade de Direito, Universidade de São Paulo, São Paulo, 2015.

MANCUSO, Rodolfo de Camargo. Divergência jurisprudencial e súmula vinculante. 4. ed. São Paulo: Revista dos Tribunais, 2010.

MARINONI, Luiz Guilherme. Julgamentos nas Cortes Supremas: precedentes e decisão do recurso diante do novo CPC. São Paulo: Revista dos Tribunais, 2015.

. Precedentes obrigatórios. 2. ed. São Paulo: Revista dos Tribunais, 2011. 
MENDES, Aluísio Gonçalves de Castro; WAMBIER, Teresa Arruda Alvim (Org.). O processo em perspectiva: jornadas brasileiras de direito processual. São Paulo: Revista dos Tribunais, 2013.

MILARÉ, Édis (Coord.). A ação civil pública após 25 anos. São Paulo: Revista dos Tribunais, 2010.

SILVER, Courtney E. Procedural hassles in multidistrict litigation: a call for reform of 28 U.S.C. $\S 1407$ and the Lexecon Result. Ohio State Law Journal, Ohio, v. 70, n. 2, p. 455-486, 2009. Disponível em: <http://moritzlaw.osu.edu/students/groups/oslj/files/2012/03/70.2.silver.pdf $>$.

TARUFFO, Michele. Le funzioni delle Corti Supreme tra uniformità e giustizia. In: DIDIER JR., Fredie et al (Coord.). Precedentes. Salvador: Juspodivm, 2015. v. 3, p. 251-262. (Coleção grandes temas do novo CPC).

. Precedente e jurisprudência. Revista de Processo, São Paulo, ano 36, v. 199, p. 139-191, set. 2011.

THEODORO JÚNIOR, Humberto; LAUAR, Maira Terra (Coord.). Tutelas diferenciadas como meio de incrementar a efetividade da prestação jurisdicional. Rio de Janeiro: GZ, 2010.

TUCCI, José Rogério Cruz e (Coord.). Direito processual civil americano contemporâneo. São Paulo: Lex Editora, 2010.

Paradoxo da corte. Um veto providencial ao novo Código de Processo Civil! Revista Consultor Jurídico, São Paulo, mar. 2015. Disponível em: <http://www.conjur.com.br/2015mar-17/paradoxo-corte-veto-providencial-cpc>. Acesso em: 25 maio 2016.

WAMBIER, Teresa Arruda Alvim; DIDIER JR., Fredie; TALAMINI, Eduardo; DANTAS, Bruno (Coord.). Breves comentários ao novo código de processo civil. 2. tir. São Paulo: Revista dos Tribunais, 2015.

ZANETI JR., Hermes (Coord.). Processo coletivo. Salvador: Juspodivm, 2016. (Coleção repercussões do novo CPC, v. 8).

ZAVASCKI, Teori Albino. Processo coletivo: tutela de direitos coletivos e tutela coletiva de direitos. 4. ed. São Paulo: Revista dos Tribunais, 2009. 